\section{Radon on the ground floor in the buildings of pre-university education in Montenegro}

\begin{abstract}
A national radon survey was performed recently in all buildings of pre-university education in Montenegro. During the school year 2016/2017, radon ${ }^{222} \mathrm{Rn}$ ) was measured with passive detectors (Radosys, RSFV type) in 2855 ground-floor rooms of 468 buildings. The average 9-month radon activity concentrations above the level of $300 \mathrm{~Bq} / \mathrm{m}^{3}$ were found in 728 rooms, which belong to 213 buildings, while in 111 rooms, belonging to 47 buildings, they were above $1000 \mathrm{~Bq} / \mathrm{m}^{3}$. Radon concentrations in the educational buildings, averaged over all sampled ground-floor rooms in a building, range from $16 \mathrm{~Bq} / \mathrm{m}^{3}$ to $2810 \mathrm{~Bq} / \mathrm{m}^{3}$, with arithmetic mean $(\mathrm{AM})=275 \mathrm{~Bq} / \mathrm{m}^{3}$. They follow a log-normal distribution with geometric mean $(\mathrm{GM})=174 \mathrm{~Bq} / \mathrm{m}^{3}$ and geometric standard deviation $(\mathrm{GSD})=2.58$. There are 135 buildings with average indoor radon concentrations on the ground floor above $300 \mathrm{~Bq} / \mathrm{m}^{3}$ and 18 buildings where they are above $1000 \mathrm{~Bq} / \mathrm{m}^{3}$. The influence of the nine factors (climate, urban/rural area, age of building, number of stories, building materials, basement, foundation slab, window frames, and heating) on radon concentrations in the buildings was analysed by univariate (UVA) and multivariate (MVA) methods. The univariate analysis revealed the significant relationship of the four factors: age of buildings, basement, building materials, and window frames with radon concentrations on the ground floor in the buildings, while multivariate analysis added to those factors urban/rural area and number of stories, but excluded building materials as a factor influencing significantly radon concentrations.
\end{abstract}

Keywords: Ground-floor rooms • Pre-university institutions • Radon-222 • Univariate and multivariate analysis

P. Vukotic

Montenegrin Academy of Sciences and Arts

R. Stijovica 5, 81000 Podgorica, Montenegro

E-mail: pvukotic@canu.ac.me

R. Zekic, T. Andjelic, N. Svrkota

Centre for Ecotoxicological Research

Bulevar S. De Gola 2, 81000 Podgorica, Montenegro

A. Djurovic

Deloitte d.o.o, Building Maxim

Bulevar Sv. Petra Cetinjskog, 81000 Podgorica, Montenegro

\section{A. Dlabac}

Centre for Nuclear Competence

University of Montenegro

Dz. Vasingtona bb, 81000 Podgorica, Montenegro

Received: 10 September 2019

Accepted: 7 January 2020

\section{Introduction}

Montenegro is a European country on the Adriatic Sea (Fig. 1), with a total land area of $13812 \mathrm{~km}^{2}$ and a population of about 620000 . It is officially divided into 23 municipalities, and unofficially in three regions: coastal, central, and northern. The Mediterranean climate with hot and dry summers and mild winters (Cs type of climate by Köppen) is present in the coastal region and in the valleys in municipalities of Podgorica and Danilovgrad, the snow-boreal climate (Df type), with fresh summers and cold winters and without dry season, exists in the region of high mountains in the northern part of the country, while the mild and wet climate with warm summers (Cf type of climate) is present in the rest of the country [1].

Radon $\left({ }^{222} \mathrm{Rn}\right)$ measurements in Montenegrin homes for the first nationwide survey were completed at the end of 2015, and the main results are published recently $[2,3]$. Immediately after finishing measurements in homes, a national survey of radon in the buildings of pre-university education began. In total, there are 247 institutions of pre-university education in Montenegro - kindergartens, schools (primary, high and vocational), institutes (where the 


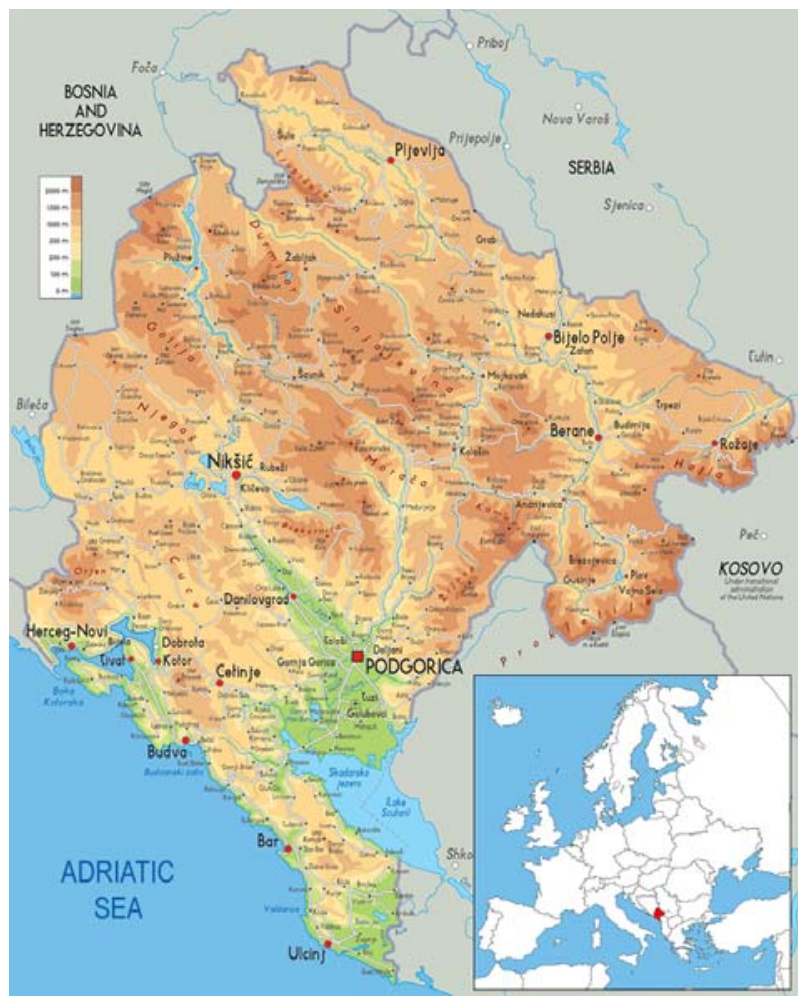

Fig. 1. The geographical setting of Montenegro.

education of children with special needs is carried out) and student dormitories. These institutions are located in 519 buildings all over the country.

Buildings of pre-university education in Montenegro are usually low-rise ones, mostly with only one (ground) floor or two floors, rarely with three floors and very seldom with more floors. In towns, most of these buildings have a very large contact area with the ground, while in the countryside they usually do not differ from family houses. Educational buildings are typically without a basement and heated on wood or electricity, without central heating and ventilation system. Construction materials are mostly concrete and bricks, while in countryside stone houses prevail.

In 1998, Montenegro adopted an annual average radon activity concentration of $400 \mathrm{~Bq} / \mathrm{m}^{3}$ as the national reference level for dwellings and $1000 \mathrm{~Bq} / \mathrm{m}^{3}$ for working places. Now, as a candidate country to join the European Union, Montenegro has to comply with directive 2013/59/Euratom [4] and new international standards [5], which require establishing a national reference level for indoor radon annual average activity concentration not higher than $300 \mathrm{~Bq} / \mathrm{m}^{3}$. This reference level also applies to the buildings where members of the public spend considerable periods of time, such as kindergartens, schools, and hospitals.

Radon in schools and kindergartens has been studied in many countries worldwide, and two reviews are published in 2012 [6] and 2018 [7], both with a very extensive list of references. Also, an IAEA publication [8] deals with protection against radon in workplaces other than mines, schools and kindergartens being among them.

This paper is aimed to present radon levels in ground-floor rooms of the pre-university institution in Montenegro and to analyse the influence of some regional and building factors on them.

\section{Materials and methods}

In preparation for the radon survey, training was organized for representatives of all educational institutions on the method of radon measurement and on completing of accompanying questionnaire. Then, a required number of detectors were assigned to each of them.

Radon measurement was carried out in all 519 buildings used for pre-university education in Montenegro. Radon was measured by passive detectors continuously throughout the school year 2016/2017 (September 2016-June 2017), in all classrooms, playrooms, offices, and bedrooms on the ground floor, as well as in some rooms on the first floor. In 3793 sampled rooms, 4078 radon detectors were deployed, of which 3793 were basic and 285 control detectors (set paired with basic detectors, approximately at every 12 th location).

Due to the planned nine-month-long measurements and expectation that radon concentration in some ground-floor rooms could be very high, at a level of several thousand $\mathrm{Bq} / \mathrm{m}^{3}$, RSFV radon detectors by Radosys were selected. This type of detector has two CR-39 chips of different sensitivities, and, according to the manufacturer's leaflet [9], has a sensitivity for radon ${ }^{222} \mathrm{Rn}$ ) up to $80 \mathrm{MBq} \cdot \mathrm{h} / \mathrm{m}^{3}$, while it is not sensitive to thoron $\left({ }^{220} \mathrm{Rn}\right)$ and gamma radiation. After 9-month exposure, detectors are sent back to the Radosys' laboratory for etching and track counting.

During the radon survey, $11.4 \%$ of detectors were lost or damaged, so that the average radon activity concentrations are obtained for 3343 rooms in 507 buildings of the pre-university education. Of them, 2855 rooms are on the ground floor, belonging to 468 buildings. Radon concentrations in ground-floor rooms of these buildings are in focus of this article.

It happened that in four ground-floor rooms both chips of radon detectors were saturated already at the exposure level of $24 \mathrm{MBq} \cdot \mathrm{h} / \mathrm{m}^{3}$, which corresponds approximately to a radon concentration of $3600 \mathrm{~Bq} / \mathrm{m}^{3}$. Therefore, the radon activity concentrations in these rooms were arbitrary taken as equal to $4000 \mathrm{~Bq} / \mathrm{m}^{3}$.

Data obtained during the radon survey were statistically evaluated and analysed using the $R$ software.

\section{Results and discussion}

The descriptive statistics of average 9-month radon activity concentrations in 2855 ground-floor rooms and mean radon concentrations on the ground floor in 468 educational buildings, to whom these rooms belong, is given in Table 1, while the frequency distribution of the average radon concentrations $\bar{C}_{\mathrm{Rn}}$ on the ground floor in those buildings is presented in Fig. 2.

The mean values of the average radon concentrations on ground floor in the educational buildings, 
Table 1. Radon activity concentrations in ground-floor rooms and educational buildings (ground-floor rooms, averaged)

\begin{tabular}{lrcccccccc}
\hline & $\mathrm{N}$ & $\begin{array}{c}\mathrm{AM} \\
{\left[\mathrm{Bq} / \mathrm{m}^{3}\right]}\end{array}$ & $\begin{array}{c}\mathrm{SD} \\
{\left[\mathrm{Bq} / \mathrm{m}^{3}\right]}\end{array}$ & $\begin{array}{c}\text { Range } \\
{\left[\mathrm{Bq} / \mathrm{m}^{3}\right]}\end{array}$ & $\begin{array}{c}\mathrm{MED} \\
{\left[\mathrm{Bq} / \mathrm{m}^{3}\right]}\end{array}$ & $\begin{array}{c}\mathrm{GM} \\
{\left[\mathrm{Bq} / \mathrm{m}^{3}\right]}\end{array}$ & $\mathrm{GSD}$ & $\begin{array}{c}C_{\mathrm{Rn}}>300 \\
\mathrm{~Bq} / \mathrm{m}^{3}\end{array}$ & $\begin{array}{c}C_{\mathrm{Rn}}>1000 \\
\mathrm{~Bq} / \mathrm{m}^{3}\end{array}$ \\
\hline Rooms & 2855 & 261 & 364 & $3-4000$ & 142 & 152 & 2.72 & $25.5 \%$ & $3.9 \%$ \\
Buildings & 468 & 275 & 324 & $16-2810$ & 169 & 174 & 2.58 & $28.8 \%$ & $3.8 \%$ \\
\hline
\end{tabular}

Notes: AM - arithmetic mean, GM - geometric mean, GSD - geometric standard deviation, MED - median, N - number of dwellings.

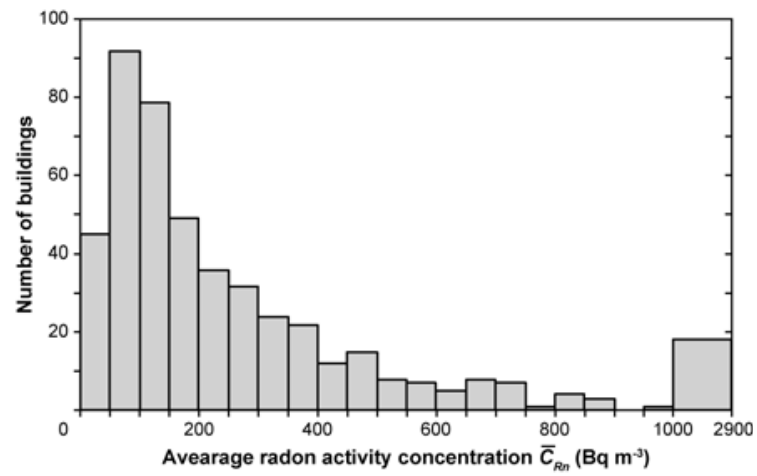

Fig. 2. The frequency distribution of the average radon concentrations $\bar{C}_{\mathrm{Rn}}$ in educational buildings (ground-floor rooms).

$\mathrm{AM}=275 \mathrm{~Bq} / \mathrm{m}^{3}$ and $\mathrm{GM}=174 \mathrm{~Bq} / \mathrm{m}^{3}$, are twice higher than combined averages for 42 national and regional indoor radon surveys of children's institutions in European countries $\left(\mathrm{AM}=130 \mathrm{~Bq} / \mathrm{m}^{3}\right.$ and $\mathrm{GM}=84 \mathrm{~Bq} / \mathrm{m}^{3}$ ) [7]. Table 1 also shows that radon concentrations, averaged on all ground-floor rooms in the building, above the level of $300 \mathrm{~Bq} / \mathrm{m}^{3}$ which is recommended by the Council Directive 2013/59 [4] as the maximum national reference level (average annual), are found in $28.8 \%$ of the educational buildings. This means that at least each forth building of the pre-university education in Montenegro has an issue with radon exposure. In $3.8 \%$ of surveyed educational buildings average radon concentrations on the ground floor are even above $1000 \mathrm{~Bq} / \mathrm{m}^{3}$, which could be considered as a level above which the exposure to radon should be optimized with the highest priority.

The Q-Q plot in Fig. 3 shows that average radon concentrations $\bar{C}_{\mathrm{Rn}}$ on the ground floor in the educational buildings follow closely a log-normal distribution, except at the lower edge. This is confirmed by

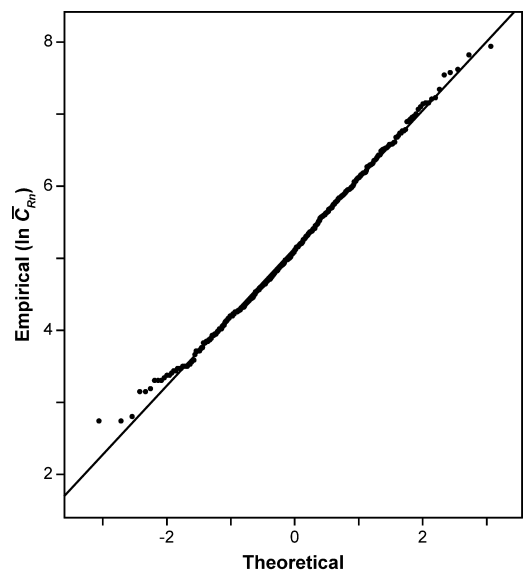

Fig. 3. Q-Q plot of experimental vs. theoretical quantiles for average radon concentrations $\bar{C}_{\mathrm{Rn}}$ in educational buildings.
Kolmogorov-Smirnov and Shapiro-Wilk tests which give $p$-values of 0.93 and 0.40 , respectively, for these radon concentrations.

The influence of nine regional and building factors: urban/rural area, climate zone, age of buildings, number of stories, presence of basement, thickness of foundation slab, building materials, window frames, and heating on radon concentrations on the ground floor in the 468 educational buildings were analysed by the univariate (UVA) and multivariate (MVA) method. Both statistical methods were applied to the logarithmically transformed data for radon concentrations $\left(\ln \bar{C}_{\mathrm{Rn}}\right)$ as a dependent variable and the factors as independent variables.

UVA was used to test the significance of the influence of the nine factors independently and to compare the mean radon values associated with the different categories of the factors. The null hypothesis was that there is no difference in mean values for a pair of categories. If there are only two categories of a studied factor, a $t$-test was applied, while in a case when the factor has more than two categories analysis of variance (ANOVA) was used. The result of $t$-test is the $p$-value, based on which the null hypothesis should be rejected if it is below a threshold of significance $(p<0.05)$. The result of ANOVA is the $p$-value of $F$-test for a factor on the whole, as well as values of p.adjust for individual testing of differences of mean values of all pairs of factor's categories. Here, a $p$-value less than 0.05 means that there is at least one pair of categories for which the difference of their mean values is statistically significant, while p.adjust values less than 0.05 show which pairs of categories have significantly different mean values. The results of the UVA analysis are given in Table 2 .

Table 2 shows that only four of the nine studied factors have an influence on indoor radon activity concentrations on the ground floor in the educational buildings. These factors are as follows: year of construction, basement, building materials, and window frames. For the year of construction only two pairs of categories, 5-3 and 6-3, make difference, that is, there is a statistically significant difference in mean values of radon concentrations in the new buildings (built after 1980) and those built in the period of country reconstruction after World War II (period 1945-1963). As to the building materials, also only two pairs of categories, 6-4 (wood-stone) and 7-6 (combination of wood with other materials), have significantly different mean values of radon concentrations, with higher mean values for stone than for wooden buildings and lower mean values for wooden buildings than for those made of wood with combination of other materials. 
Table 2. Results of the univariate analysis (UVA) for 468 buildings (ground-floor rooms, averaged)

\begin{tabular}{|c|c|c|c|c|}
\hline Factors & Pair of categories & Difference (95\% CI) & $p$-value & p.adjust \\
\hline$\overline{\text { Area }}$ & Urban/rural & $0.14(-0.03-0.31)$ & 0.098 & \\
\hline Climate zone & $\begin{array}{l}\text { Cf-Cs } \\
\text { Df-Cs } \\
\text { Df-Cf }\end{array}$ & $\begin{array}{r}0.11(-0.11-0.33) \\
-0.27(-0.71-0.17) \\
-0.38(-0.81-0.04)\end{array}$ & 0.081 & $\begin{array}{l}0.466 \\
0.314 \\
0.090\end{array}$ \\
\hline Year of construction & $\begin{array}{l}2-1 \\
3-1 \\
4-1 \\
5-1 \\
6-1 \\
3-2 \\
4-2 \\
5-2 \\
6-2 \\
4-3 \\
5-3 \\
6-3 \\
5-4 \\
6-4 \\
6-5\end{array}$ & $\begin{aligned} &-0.02(-0.83-0.79) \\
& 0.00(-0.71-0.72) \\
&-0.15(-0.86-0.56) \\
&-0.43(-1.14-0.28) \\
&-0.52(-1.28-0.24) \\
& 0.02(-0.50-0.54) \\
&-0.14(-0.65-0.38) \\
&-0.41(-0.93-0.10) \\
&-0.50(-1.08-0.08) \\
&-0.16(-0.50-0.19) \\
&-0.43(-0.78--0.08) \\
&-0.52(-0.96--0.08) \\
&-0.28(-0.62-0.06) \\
&-0.37(-0.80-0.06) \\
&-0.09(-0.52-0.34)\end{aligned}$ & 0.001 & $\begin{array}{l}1.000 \\
1.000 \\
0.990 \\
0.509 \\
0.368 \\
1.000 \\
0.976 \\
0.204 \\
0.136 \\
0.796 \\
0.006 \\
0.009 \\
0.180 \\
0.146 \\
0.993\end{array}$ \\
\hline Basement & Yes/No & $-0.43(-0.68--0.18)$ & 0.001 & \\
\hline Foundation slab thickness & $\begin{array}{l}\leq 5 \mathrm{~cm}-0 \mathrm{~cm} \\
>5 \mathrm{~cm}-0 \mathrm{~cm} \\
>5 \mathrm{~cm}-\leq 5 \mathrm{~cm}\end{array}$ & $\begin{array}{l}-0.14(-0.52-0.24) \\
-0.14(-0.45-0.16) \\
-0.01(-0.30-0.28)\end{array}$ & 0.537 & $\begin{array}{l}0.679 \\
0.511 \\
0.998\end{array}$ \\
\hline Stories & $\begin{array}{r}2-1 \\
3-1 \\
>3-1 \\
3-2 \\
>3-2 \\
>3-3\end{array}$ & $\begin{array}{r}0.10(-0.14-0.35) \\
-0.04(-0.43-0.34) \\
-0.44(-1.55-0.66) \\
-0.15(-0.55-0.25) \\
-0.55(-1.66-0.56) \\
-0.40(-1.55-0.75)\end{array}$ & 0.424 & $\begin{array}{l}0.688 \\
0.991 \\
0.727 \\
0.774 \\
0.578 \\
0.805\end{array}$ \\
\hline Building materials & $\begin{array}{l}2-1 \\
3-1 \\
4-1 \\
5-1 \\
6-1 \\
7-1 \\
3-2 \\
4-2 \\
5-2 \\
6-2 \\
7-2 \\
4-3 \\
5-3 \\
6-3 \\
7-3 \\
5-4 \\
6-4 \\
7-4 \\
6-5 \\
7-5 \\
7-6\end{array}$ & $\begin{array}{r}-0.11(-0.60-0.38) \\
-0.02(-0.45-0.40) \\
0.23(-0.21-0.67) \\
0.14(-0.35-0.62) \\
-0.50(-1.16-0.16) \\
2.40(-0.38-5.19) \\
0.09(-0.35-0.52) \\
0.34(-0.11-0.78) \\
0.24(-0.24-0.73) \\
-0.39(-1.05-0.28) \\
2.51(-0.28-5.30) \\
0.25(-0.12-0.62) \\
0.16(-0.27-0.58) \\
-0.47(-1.09-0.15) \\
2.43(-0.35-5.20) \\
-0.09(-0.53-0.34) \\
-0.72(-1.35--0.10) \\
2.18(-0.60-4.96) \\
-0.63(-1.29-0.03) \\
2.27(-0.52-5.06) \\
2.90(0.08-5.72)\end{array}$ & 0.002 & $\begin{array}{l}0.995 \\
1.000 \\
0.720 \\
0.982 \\
0.286 \\
0.143 \\
0.997 \\
0.273 \\
0.756 \\
0.602 \\
0.109 \\
0.425 \\
0.928 \\
0.268 \\
0.132 \\
0.996 \\
0.012 \\
0.237 \\
0.071 \\
0.196 \\
0.040\end{array}$ \\
\hline Window frames & Wood-PVC/Al & $-0.51(-0.69--0.33)$ & 0.000 & \\
\hline Heating & $\begin{array}{c}\text { Wood/Coal - None } \\
\text { Electric/Central - None } \\
\text { Electric/Central-Wood/Coal }\end{array}$ & $\begin{array}{r}1.26(-0.97-3.49) \\
1.18(-1.05-3.41) \\
-0.08(-0.29-0.13) \\
\end{array}$ & 0.302 & $\begin{array}{l}0.381 \\
0.427 \\
0.662 \\
\end{array}$ \\
\hline
\end{tabular}

Notes: Year of construction: 1 - before the year 1900, 2 - 1900-1944, 3-1945-1963, 4 - 1964-1979, 5-1980-1999, 6 - the year 2000 and later. Building materials: 1 - concrete, 2 - bricks, 3 - concrete and bricks, 4 - stone, 5 - stone and concrete/ bricks, 6 - wood, and 7 - wood and concrete/bricks/stone. 
Table 3. Results of the multivariate analysis (MVA) for 468 buildings (ground-floor rooms, averaged)

\begin{tabular}{|c|c|c|c|c|}
\hline Factors and their categories & Buildings & Estimate (SE) & $t$-value & $p$-value \\
\hline \multicolumn{5}{|l|}{ Area } \\
\hline Rural & 250 & 0 & & \\
\hline Urban & 218 & $-0.26(0.11)$ & -2.42 & 0.016 \\
\hline \multicolumn{5}{|l|}{ Year of construction } \\
\hline Before 1900 & 16 & 0 & & \\
\hline 1900-1944 & 34 & $-0.05(0.28)$ & -0.16 & 0.872 \\
\hline $1945-1963$ & 114 & $0.06(0.24)$ & 0.26 & 0.797 \\
\hline 1964-1979 & 125 & $-0.04(0.24)$ & -0.15 & 0.878 \\
\hline 1980-1999 & 120 & $-0.47(0.24)$ & -1.93 & 0.055 \\
\hline 2000 and later & 56 & $-0.57(0.26)$ & -2.18 & 0.030 \\
\hline \multicolumn{5}{|l|}{ Basement } \\
\hline Yes & 46 & 0 & & \\
\hline No & 418 & $0.42(0.15)$ & 2.83 & 0.005 \\
\hline \multicolumn{5}{|l|}{ Stories } \\
\hline One & 256 & $4.64(0.27)$ & 17.14 & 0.000 \\
\hline Two & 159 & $4.82(0.28)$ & 17.25 & 0.000 \\
\hline Three & 48 & $4.54(0.30)$ & 15.03 & 0.000 \\
\hline More than three & 5 & $4.35(0.48)$ & 9.14 & 0.000 \\
\hline \multicolumn{5}{|l|}{ Window frames } \\
\hline Wood & 181 & 0 & & \\
\hline $\mathrm{PVC} / \mathrm{Al}$ & 255 & $0.68(0.10)$ & 6.94 & 0.000 \\
\hline
\end{tabular}

The mean values of radon concentrations are higher in buildings without a basement and in buildings with window frames made of PVC and aluminium. It was somewhat unexpected that the UVA did not show a statistically significant influence of the area and climate factors on indoor radon concentrations, while this is not a case with the slab thickness factor because the data were not taken from the construction plans but provided by users of buildings, which make them not reliable enough.

To examine the effect of all studied factors simultaneously on the radon activity concentrations in the buildings, MVA was employed. A backward stepwise regression was applied to the $\ln \bar{C}_{\mathrm{Rn}}$ data to identify statistically significant factors that affect radon concentrations. Even if only one category of a studied factor has statistical significance ( $p$-value less than 0.05), then that factor in whole is statistically significant. For all studied factors, one of the categories was used as a benchmark with coefficient equal zero.

The results of the MVA are given in Table 3. They show that the five factors: area, number of stories, presence of a basement, year of construction, and window frames have a statistically significant influence on the radon activity concentrations on the ground floors of the buildings. This means that the regression excluded the building materials as a factor, which the UVA has found to have an influence on radon concentrations in buildings, but added as significantly influential the two factors, namely, urban/rural area and a number of stories, which the UVA did not recognize as being significant.

The replacement of the influence of building materials on indoor radon concentrations, found by the UVA, with the influence of the factors area and number of stories, in the MVA, could be explained by a dependence of choice of building materials on location of building (urban or rural) and on number of stories, the latter also being dependent on urban/rural area. The findings of MVA have more relevance because, in fact, all investigated factors act simultaneously, while some of them make a significant influence on radon indoor concentrations and some not.

Table 3 shows that the only category making differences in the year of construction factor are the newest educational buildings, built in 2000 and later, in comparison with the benchmark category. This finding of the MVA is only slightly different from the corresponding one obtained by the UVA. In the other four influencing factors, there are statistically significant differences between all their categories in comparison with the respective benchmark category.

\section{Conclusions}

Radon concentrations in ground-floor rooms in the buildings of pre-university education in Montenegro are, on average, relatively high. Their mean values for 2855 rooms are $\mathrm{AM}=261 \mathrm{~Bq} / \mathrm{m}^{3}$ and $\mathrm{GM}=$ $152 \mathrm{~Bq} / \mathrm{m}^{3}$. The maximum 9-month average value, higher than $3600 \mathrm{~Bq} / \mathrm{m}^{3}$, was found in four rooms. The mean values of radon concentrations in 468 buildings, averaged over all sampled ground-floor rooms in a building, are $\mathrm{AM}=275 \mathrm{~Bq} / \mathrm{m}^{3}$ and $\mathrm{GM}=174 \mathrm{~Bq} / \mathrm{m}^{3}$. The maximum average value in a building is $2810 \mathrm{~Bq} / \mathrm{m}^{3}$. In $28.8 \%$ of the educational buildings, average values of radon concentrations on the ground floor are higher than $300 \mathrm{~Bq} / \mathrm{m}^{3}$ and in $18(3.8 \%)$ buildings higher than $1000 \mathrm{~Bq} / \mathrm{m}^{3}$. The urgent reducing of radon exposure in these 18 buildings was strongly recommended to the Ministry of Education. Since then, two of these buildings have been remediated and procedure for remediation of the other five has started. The average radon concentrations on the ground floor in the educational buildings follow closely a log-normal distribution. 
The influence of nine regional and building factors (urban/rural area, climate zone, age of buildings, number of stories, presence of a basement, thickness of foundation slab, building materials, window frames, and heating) on radon concentrations in 468 educational buildings was analysed by the univariate and multivariate methods. The univariate analysis of the data for radon concentrations in buildings, averaged over all sampled ground-floor rooms in a building, revealed the significant relationship of the four factors: age of buildings, basement, building materials, and window frames with radon concentrations. In the year of construction factor, only two of 15 analysed pairs of categories have a statistically significant difference in mean values of radon concentrations. These pairs are formed of buildings built after 1980 and those built in the period of country reconstruction after World War II. Concerning building materials, also only two of 21 pairs of categories have significantly different mean values of radon concentrations, with higher mean values for stone than for wooden buildings. The mean values of radon concentrations are higher in buildings without a basement and in buildings with window frames made of PVC and aluminium.

The multivariate analysis added the urban/rural area and a number of stories to those factors but excluded the building materials as a factor influencing significantly radon concentrations. The newest educational buildings, built after 2000 , are only one of six categories in the year of construction factor that makes a difference in the mean radon concentrations. In the other four influencing factors, there are statistically significant differences in the mean values of radon concentrations in the buildings between all their investigated categories.

Acknowledgment. The article presents a part of the research conducted within the IAEA TC project MNE9005 "Assessing and reducing radon in schools and kindergartens", funded in the period $2016-2018$ by the International Atomic Energy Agency and Government of Montenegro. The authors would like to thank the Government of Montenegro and the International Atomic Energy Agency for making this research possible.

\section{ORCID}

P. Vukotic (D) http://orcid.org/0000-0002-4232-2636

\section{References}

1. Buric, M., Micev, B., \& Mitrovic, L. (2012). Atlas of climates in Montenegro. Podgorica, Montenegro: Montenegrin Academy of Sciences and Arts. (in Montenegrin).

2. Vukotic, P., Antovic, N., Djurovic, A., Zekic, R., Svrkota, N., Andjelic, T., Svrkota, R., Mrdak, R., Bjelica, N., Djurovic, T., Dlabac, A., \& Bogicevic, M. (2019). Radon survey in Montenegro - A base to set national radon reference and "urgent action" level. J. Environ. Radioact., 196, 232-239. DOI: 10.1016/j. jenvrad.2018.02.009.

3. Vukotic, P., Antovic, N., Zekic, R., Svrkota, N., Andjelic, T., Svrkota, R., Mrdak, R., Djurovic, A., Dlabac, A., Bjelica, N., Djurovic, T., \& Bogicevic, M. (2019). Main findings from radon indoor survey in Montenegro. Radiat. Prot. Dosim., 183(3), 355-370. DOI: $10.1093 / \mathrm{rpd} / \mathrm{ncz} 022$.

4. European Union. (2013). Council Directive 2013/59/ Euratom of 5 December 2013 laying down basic safety standards for protection against the dangers arising from exposure to ionising radiation, and repealing Directives 89/618/Euratom, 90/641/Euratom, 96/29/ Euratom, 97/43/Euratom and 2003/122/Euratom. Official Journal of the European Union, OJ L13, 17.1.2014, 1-73. https://eur-lex.europa.eu/legalcontent/EN/TXT/?uri=OJ:L:2014:013:TOC.

5. International Atomic Energy Agency. (2014). Radiation protection and safety of radiation sources. Vienna: IAEA. (Safety Standards Series No. GSR, Part 3).

6. Vaupotič, J. (2012). Radon in kindergartens and schools - A review. In Z. Li \& C. Feng (Eds.), Handbook of radon: Properties, applications and health (pp. 477-524). New York: Nova Science Publishers.

7. Zhukovsky, M., Vasilyev, A., Onishchenko, A., \& Yarmoshenko, I. (2018). Review of indoor radon concentrations in schools and kindergartens. Radiat. Prot. Dosim., 181(1), 6-10. DOI: 10.1093/rpd/ncy092.

8. International Atomic Energy Agency. (2003). Radiation protection against radon in workplaces other than mines. Vienna: IAEA. (Safety Report Series No. 33; STI/PUB/1168).

9. Radosys Dosimetric Microscopy. (2019). Radosys leaflet. Retrieved July 10, 2019, from http://www.radosys. com/rsfv\&rsfw.htm. 